\title{
Benevolent State, \\ Law-Breaking Smugglers, and \\ Deportable and Expendable Women: An Analysis of the Canadian State's Strategy to Address Trafficking in Women
}

\author{
Sunera Thobani
}

\section{Abstract}

The Canadian state undertook a major restructuring of the immigration and refugee program in the 1990s, committing itself to creating a new immigration act as part of this process. ${ }^{1}$ Trafficking is one major issue that the new act would concern itself with. In this paper I make the case that the state's proposals for addressing trafficking enable the state to posit itself as responsible for protecting "Canadians" while carefully avoiding any responsibility for the wellbeing of women who are trafficked; demonize smugglers as the cause of trafficking; and override the concerns and interests of women who are trafficked by making deportation the only "solution" to their presence in Canada. Consequently, these proposals will further penalize the women, while protecting the interests of the Canadian men, women, and employers who profit and benefit from their exploitation. Further, while this approach does nothing to address the root causes of trafficking, the state's enthusiasm for increasing trade liberalization will only exacerbate these very causes. ${ }^{2}$

\section{Résumé}

L'État canadien a entrepris une vaste opération de restructuration du programme d'immigration et $d u$ droit d'asile dans les années 9o, promettant de créer, comme partie intégrante de ce processus, une nouvelle loi sur l'immigration. ${ }^{1}$ Le trafic de personnes est l'une des grosses questions visées par la nouvelle loi. Dans le présent article, je soutiens que les propositions de l'état pour s'attaquer au trafic de personnes permettent à l'état:

- De poser comme fait acquis qu'il a la responsabilité de protéger "les Canadiens" tout en évitant toute responsabilité pour le bien-être des femmes trafiquées;

- De diaboliser les passeurs comme étant la cause du trafic;

- De passer outre les préoccupations et les intérêts des femmes trafiquées en proposant la déportation comme seule «solution » à leur présence au Canada.

Par conséquent, ces propositions vont pénaliser encore plus ces femmes tout en protégeant les intérêts des Canadiens, des Canadiennes et des employeurs qui tirent profit de leur exploitation. Il faut aussi ajouter qu'alors que cette approche ne fait rien pour s'attaquer aux causes du trafic illicite de migrants, l'enthousiasme de l'état pour étendre encore plus la libéralisation des échanges commerciaux ne fera qu'exacerber ces même causes. ${ }^{2}$ 


\section{Introduction}

$\mathrm{O}$ n April 6, 2000, the minister of Immigration and Citizenship, Elinor Caplan, tabled Bill c-31, a pro posal for a new Immigration and Refugee Protection Act. In discussing C-31, the minister stressed that she was introducing a "tough" bill that would "close the back door to those who would abuse the system." 3 The bill is tough indeed, introducing more restrictive criteria for future immigration into Canada, as well as undermining some of the rights currently allowed to landed immigrants. Its general focus on "abuse" and on measures to curtail "criminality" in effect further the anti-immigrant and refugee political climate prevailing in Canada in the 199os. Indeed, it tars all immigrants and refugees as potential criminals from whom Canadians need to be protected. The tone of the bill, as that of much of the official discourse on immigration in the 1990s, is based on the assumption that most incoming immigrants and refugees are guilty—of wanting to abuse the system at best, and of being actively engaged in criminality at worst-until they prove themselves innocent, and therefore deserving of the Canadian generosity that would allow them to enter the country.

One significant feature of the bill is the creation of a new offence for the smuggling of human beings, by which the state seeks to tackle the issue of trafficking. ${ }^{4}$ The trafficking of women and children has emerged as a major international concern since the First World War. ${ }^{5}$ While the migrations of men and women, coerced and "voluntary," have been a central feature of the global integration of economies within the capitalist system of relations for at least the last five hundred years, the current phase of globalization is resulting in an escalation of migrations from the countries of the South into the North. The trafficking of women is a major component of this migration, and Canada, much like other countries in the North, is a receiving country for women who have been trafficked from the countries of the South.

A number of studies have pointed out that factors pulling women into the global trafficking network include poverty, personal histories of violence and abuse, lack of other work options, and responsibility for providing for family and community members. ${ }^{6}$ Important as these factors are, however, no less significant a factor in global trafficking are the immigration policies of receiving countries. ${ }^{7}$ The women who are trafficked work overwhelmingly in the informal sectors of the economy, and most countries in the North have extremely restrictive immigration policies controlling the labour of workers in these sectors. Thus, women are trafficked through the interplay of the underlying economic and social conditions within the global economy, as well as through the state policies and practices of receiving countries that construct their illegality, and hence their vulnerability to being exploited. There is nothing inherent in the women themselves that makes them prone to being "trafficked women," as the unproblematic use of the category would suggest. The unproblematized use of this category in mainstream discourse "naturalizes" their experience; it defines trafficking as the fault of Third World women and their communities; and it seeks to draw attention to the policies of receiving countries as a response to this problem originating elsewhere, and somehow inherent in the women themselves. A much more fruitful approach is to examine how women are "made" into trafficked women, by examining state practices and policies, and by examining the underlying social relations within the global economy. This is the framework for my paper, which recognizes the issues involved to be much more complex than the question of the abuse of the women by traffickers, drawing attention instead, in this instance, to the conditions in the receiving countries that create the women's legal, economic, and social vulnerabilities, and that crystallize their status as trafficked women. The analysis in this paper therefore focuses on immigration policies in Canada as a receiving country, and argues that the Canadian state, rather than playing the benevolent role it seeks to construct for itself, shapes immigration policies and practices in myriad ways that make the state complicit in, and responsible for, the very functioning and growth of trafficking in women.

Research into trafficking has been extremely sparse in Canada. The research undertaken by the Global Alliance against Trafficking in Women (GAATW) and the Philippine Women's Centre (PWC) has revealed that women are trafficked into "various sites within the informal and invisible sectors of the economy," key among which are the sex trade and entertainment industry, and the marriage market and trade in mail-order brides. As both organizations are quick to point out, however, the two sites are not mutually exclusive: these sites often intersect, with women who are brought in for one being forced into the other after their arrival. The PWC and GAATw have identified domestic workers and immigrant mail-order brides ${ }^{9}$ as two groups that are "susceptible to situations involving trafficking." In addition, the GAATw has also found trafficked women to be engaged in sex work in "bawdy houses" and massage parlours in Vancouver ${ }^{10}$ and Toronto. ${ }^{11}$ Based upon GAATw find- 
ings, significant numbers of women can be estimated to be working in "bawdy houses" and massage parlours in Vancouver, providing sexual services.

The women are all Asian, most of them have had their passports taken away, they are in the country illegally, they are made to provide sexual services and there is absolutely nothing there in place to take care of them in case of violence or abuse. We were also told that these women often work under conditions of debt bondage, and have a debt of \$30,000which they have to pay to the brokers who have brought them over. So, if there are 40 massage parlours with an average of 20 women in each, you can get an idea of the number of women working under mostly invisible and possibly coercive situations in Vancouver alone. ${ }^{12}$

Presumably, a similar situation exists in other major cities across the country.

Anecdotal evidence gathered from the experiences of front-line service workers suggests that women who are trafficked enter and reside in the country through both legal routes (for example, as mail-order brides, or on temporary employment authorizations), as well as through extra-legal ones (for example, with forged documents, or by overstaying on a visitor visa or a temporary employment authorization). The notion that all trafficked women enter the country illegally is unwarranted, as a recent research project undertaken in northern British Columbia demonstrates. ${ }^{13}$

Given that women who are trafficked enter the country through whatever channels are available to them, the immigration legislation and practices most relevant would be the family-class and sponsorship regulations (especially for fiancé[e]s and mail-order brides), the legislation affecting temporary workers (for women who work as entertainers and in the sex trade) and domestic workers, as well as the treatment of undocumented or extra-legal migrants. ${ }^{14}$

Under the point system institutionalized by the Immigration Act, 1976-77, the main categories of immigration into Canada are the independent class (which allows the immigration of skilled workers, business investors, entrepreneurs, and the self-employed); the family class (which allows sponsorship of specific family members); and the refugee program (for those meeting the UN Convention definition of refugee). Entry into Canada is also allowed for limited periods (i.e., for non-immigrants) under the categories of students, visitors, non-immigrant workers (allowed into the country on temporary employment authorizations), and under the Live-In Care Giver Program (LCP) for domestic workers (who are eligible to apply for landed status after working in domestic service for two years).
Additionally, migrants are known to enter and reside in the country through extra-legal channels, and with undocumented status. Although very little research has been undertaken on this group, and very little is known about the circumstances under which they enter and reside in Canada, this form of migration is internationally acknowledged to be increasing significantly. ${ }^{15}$

\section{Proposed Changes for a New Immigration Act}

The proposals for the new immigration act seek to maintain the distinction of the independent/economic class from the family class, with unequal conditions for the entry of each class. The classes of temporary workers and visitors are to be maintained as well. This would mean that the distinction between immigrants (those allowed into the country for permanent settlement, and subsequently eligible to claim citizenship) and migrants (those officially allowed into the country for a temporary period and hence ineligible to claim citizenship) is to be preserved. This distinction is crucial for women who have been trafficked. Women who enter the country to work in informal sectors are rarely granted permanent resident status, which would subsequently allow them to claim citizenship status. Instead, the precarious official status of temporary visas creates the vulnerability of the women who are brought into the country on short-term permits, denying them the greater labour mobility they would have if their status was that of landed immigrants.

\section{The Family Class}

An adult Canadian citizen or a landed immigrant can currently sponsor specified family members for immigration into the country, and these include fiancé(e)s and wives. The sponsor is required to demonstrate that he or she will be able to provide financially for the basic needs of the dependent. The sponsor makes a commitment to the government of Canada to provide for all of her or his dependents for a prescribed period of time (up to ten years), and defaulting on this commitment can mean that legal action will be taken against the sponsor. However, in the case of the sponsorship of a spouse, the financial requirement can be eased. In the specific case of the sponsorship of a fiancé(e), the sponsor and fiancé(e) need to prove they are free to marry, and are given ninety days within which the marriage must take place. ${ }^{16}$ The permanent-resident status of a sponsored fiancé(e)s is therefore made conditional upon the marriage taking place.

The sponsorship requirement makes the sponsored immigrant dependent upon her sponsor for her entry, and 
stay, in Canada for the duration of the sponsorship agreement. In effect, the sponsored immigrant is prohibited from making claims to social-assistance programs for the sponsorship period, because the sponsor is made responsible for providing for her basic needs. Should the sponsorship agreement break down, it is only at the discretion of provincial social-service agencies that social assistance is provided, if any, to the sponsored immigrant. The sponsored immigrant has no official right to claim such assistance, even if employed and paying taxes.

For women who enter the country as sponsored immigrants (as, for example, mail-order brides or fiancées), this circumstance of enforced dependency makes them extremely vulnerable to the power their sponsors have over them by virtue of being able to withdraw sponsorship and threaten to deport them. A pattern of dominance imposed during this ninety-day period could set the power dynamics within the relationship for the future. This threat of deportation by the sponsor has repeatedly been identified by front-line workers as a major factor in trapping sponsored immigrant women into a relationship of powerlessness with their sponsor, making the women vulnerable to violence and abuse.

Women who are sponsored as mail-order/immigrant brides by men would therefore be extremely vulnerable to this power that the state grants the sponsor over "their" women. The GAATw estimates that "mail-order/immigrant brides" come from "... Asia and also from the Caribbean and other parts of the world [and] are married to men who live in isolated fishing and forest communities, particularly in the northern communities," and that they are " ... isolated, atomized in their households, and may not know what their rights are." ${ }^{17}$ It should be noted that while migrating to more rural areas and into small towns might compound the isolation experienced by sponsored immigrant women, the sponsorship requirement in itself makes the women dependent upon the sponsor, and hence inevitably increases their isolation, while correspondingly increasing the power of the sponsor to control their lives. Other factors, such as the everyday racism these women experience, as well as any language barriers they may face, would also further increase their vulnerability and powerlessness.

The proposed act would reinforce the sponsorship relationship and its requirements. ${ }^{18}$ Furthermore, the proposals contain stringent financial obligations for permanent residents, making inadmissible those individuals unable to support themselves or whose sponsors are unable to do so. ${ }^{19}$ Given that women who are trafficked are likely to be in the country without the financial means to sup- port themselves, and are likely to be deeply indebted, this requirement would likely bar them from getting permanent resident status. For women who may be in transition, having escaped the control of the men who traffic them, and who may have no immediate means of supporting themselves, this requirement would render them inadmissible. In the case of women who have experienced severe abuse and violence, the restrictions for admissibility on the grounds of "excessive demand on health or social services" could be a severe obstacle to overcome. ${ }^{20}$ Mandatory exemptions from these restrictions would best serve these women who have been trafficked. For the women who have been subjected to violence, or who are traumatized by having been trafficked, and may therefore require health and social services, their admissibility needs to be assured, irrespective of any financial considerations.

Perhaps more pernicious in the proposals is the introduction of "misrepresentation" as a grounds for inadmissibility. Sections 36 (1) and 36 (2) outline inadmissibility for a period of two years for individuals "directly or indirectly making a misrepresentation or withholding information on a relevant matter" that affects the administration of the legislation. This means that sponsored women making misrepresentations about themselves would become inadmissible. However, this inadmissibility on the grounds of misrepresentation would also be extended to individuals sponsored by someone making the misrepresentation, as laid out in section 36 (1) (b). Therefore if a sponsor makes the misrepresentation, the person sponsored could become inadmissible. Women would become inadmissible even if they did not know that their sponsor had made misrepresentations about his or her status, and/or about their own status. So, for example, if a sponsor has misrepresented his or her status in order to immigrate to Canada, and upon receiving landed status decides to sponsor a fiancé(e) or spouse without revealing the misrepresentation, the fiancé(e) or spouse might become inadmissible through no fault of her own. Likewise, if a married man sponsors a "fiancée" without revealing to her his married status, it is the fiancée who could become inadmissible, again through no fault of her own. Should sponsored women be deliberately misled by their sponsors, the proposed act (section $36[1][b]$ ) would penalize these women, who might not have misrepresented themselves in any manner, and might have no prior knowledge about the misrepresentations made by of their sponsors.

One significant change to the sponsorship regulation by Citizenship and Immigration Canada, announced April 6,2000 , is that sponsorship will be denied to individuals convicted of spousal abuse. This is an interesting approach 
to the problem of violence against women. The state now requires sponsored immigrant women to become dependent on male sponsors if they are to enter the country, making them more vulnerable to abuse and violence, so there is little likelihood that this change will be of great benefit. Instead of doing away with this vulnerability, which places sponsored immigrant women in potentially abusive relationships, the state intends to demand that abused "dependents" engage with a criminal justice system, and only once a conviction is secured will the abusive men be barred from becoming future sponsors. The criminal justice system has repeatedly failed to protect women, and it is rife with racist and sexist practices, as numerous studies have shown. To demand sponsored women engage with this system is to place responsibility for ending the violence upon them, and not upon the sponsor. The abused spouse might also be relying on the sponsor to sponsor her children, or other dependent family members, especially if she is in a precarious financial situation that would make her ineligible to become a sponsor herself. Indeed, barring future sponsorship to violent sponsors might well make abused women stay with them in order to secure the future sponsorship of other family members by the very sponsors who are abusing them. ${ }^{21}$ Additionally, women who have been trafficked might not want to disclose this experience to criminal justice authorities, even if they wished to escape the power of abusive sponsors. Revealing that they have been trafficked, and admitting they had not revealed this to immigration officials earlier, might well make the women inadmissible on the grounds of misrepresentation.

In short, then, the proposals to strengthen sponsorship requirements will serve the interests of Canadian sponsors more than of the women they sponsor. The proposed act seeks to extract the costs for breakdown in sponsorships, for misrepresentation, and for violence in these relationships from women who have been sponsored, and not from their sponsors.

\section{Temporary Employment Authorizations}

Temporary employment authorizations are issued to workers for specific jobs, with a particular employer, for a limited period of time (usually for a year or less). In order to acquire a temporary employment authorization, temporary workers are required to have a job offer validation, a letter of support from their employer, and proof of their qualification for the job. They can also be required to present a medical clearance. Temporary workers are made dependent on their employer for their continued stay in the country, because the employment authorization specifies the period and nature of their employment. Should employers terminate the employment contract, temporary workers are officially required to leave the country.

The Philippine Women's Centre and the GAATw have found that some trafficked women enter the country as entertainers. ${ }^{22}$ For the women who enter under this category and who overstay the period specified in their employment authorizations, their status in the country becomes an extra-legal one. In cases where women who are trafficked, and have been made to work in the sex trade, are intercepted by the police or by immigration officials, their "criminalization" and deportation "tend to be the customary responses of law enforcers and immigration officials to the bulk of cases." ${ }^{23}$

The proposed changes outline the state's intention to expand the temporary workers program by adopting a "service-oriented approach" for facilitating authorizations for temporary workers, in order to better meet the needs of employers. In-Canada landing of temporary workers will be allowed, and agreements will be made with individual sectors or firms. Expansion of the temporary workers program will likely result in increased numbers of female migrant workers living and working in extremely vulnerable circumstances by making them dependent upon their employers for their continued stay in Canada. The expansion of this program will presumably enable more temporary workers to be brought into Canada to work in the informal sector, including the sex industry, as well as other industries. Employers will be able to maintain their power over the continued stay of these employees. Instead of extending the rights that other categories of workers enjoy by entering Canada as landed immigrants under the independent class, the state will continue structuring the conditions for the super-exploitation of migrant workers, including women, by giving them a precarious and vulnerable legal status in the country.

\section{Domestic Workers and the Live-In Care Giver Program}

While the history of the immigration of domestic workers into Canada can be traced to the early twentieth century, the Live-In Care Giver Program (LCP) now in effect was instituted in 1992. Under this program, women (mostly from the Philippines and the Caribbean) enter Canada to work as domestic workers. They are required to meet specific education and training criteria, and upon arrival are required to live in their place of employment. The Live-In CareGiver Program ties the women to their employers, and after working in domestic service for a period of two years, they become eligible to apply for landed immigrant status.

This program has been much criticized by domestic workers and their advocates. The live-in requirement makes 
the women dependent on their employers, not only for their conditions of work but also their living conditions, thus making them vulnerable to harassment and abuse in their private as well as public lives. Living-in also makes the women available to work long hours with little (if any) pay for overtime. Additionally, this program has the (intended?) consequence of deskilling women, for women with higher levels of education and professional training work in Canada as domestic workers. The domestic workers program is often the only means by which many women can immigrate into Canada, and their subsequent deskilling and super-exploitation within their places of employment is the price extracted from these women by Canadian immigration policy. This process of deskilling cheapens their labour in order to serve the childcare needs of affluent Canadian families. ${ }^{24}$ The live-in requirement also makes domestic workers vulnerable to being coerced into providing sexual services to their employers. The Philippine Women's Centre has recorded numerous instances of this abuse, as well as of domestic workers "marrying" their employers.

As there is no explicit reference to the Live-In Care Givers Program in the proposed changes, we may presume that current conditions for the program will be maintained for the immediate future. If this is indeed the case, then vigilance is required to ensure that current eligibility of domestic workers for landed immigrant status is not taken away. Indeed, landing domestic workers as permanent residents is immediately required in order to stop the superexploitation of domestic workers, and particularly to counter the sexual harassment that the live-in requirement enables. Given that other categories of workers are allowed into the country as landed immigrants under the point system, maintaining the Live-In Care Giver Program-which denies domestic workers the right to work in other occupations-works to racialize and feminize the provision of domestic workers' labour.

\section{Extra-legal Migrants}

Migrants entering Canada can come to have extra-legal or undocumented status in several ways. The most obvious method is by entering the country with forged travel documents. Other possible routes include overstaying on temporary visas (such as visitor or student visas), or on temporary employment authorizations. Although the treatment of these migrants varies upon their interception, the resolution of the cases they file seem to follow a depressingly similar pattern. The experiences of front-line legal workers indicates that when individual women are intercepted by the police or immigration officials, they are detained until their identity is established. The women are then processed and released while their cases are being dealt with. However, in the case of extra-legal migrants intercepted as a group, they tend to be held in detention, even while their cases are being dealt with. ${ }^{25}$ The GAATw has also found that current practice seems to be deportation of trafficked women who are in the country without legal status. ${ }^{26}$ Even when the women claim refugee status, their claims are rarely successful, and the result is the same if they apply for landed status on the basis of humanitarian and compassionate grounds.

It is extremely difficult to accurately assess how many undocumented migrants there are, for several reasons. The incredible vulnerability of such migrants makes and keeps them "invisible," and it is understandable that such migrants can be reluctant to make their circumstances public. However, this lack of public visibility changed dramatically with the arrival of approximately 600 migrants from China in the summer of 1999. The treatment of these migrants by the state drew public attention to the presence of this "problem" within Canada, and the moral panic created by the government and the media fostered a political climate of racist hostility towards this group. The Department of Immigration responded to the arrival of the migrants by holding the overwhelming majority of them in detention centres and in jails, and deporting as many of them as possible once their applications for asylum had been turned down. Only a minuscule number of the claims for asylum made by these migrants have been accepted. ${ }^{27}$

The proposed act would give broad powers of detention, including at port of entry, to immigration officers, and also expand the categories of people who can be detained. Detention is to be allowed if a designated officer has "reasonable ground to suspect" an individual is "inadmissible on the grounds of security or for violating human rights," or is a "danger to the public." ${ }^{28}$ Given that women who have been trafficked to engage in sex work could well be defined as a "danger to the public" in a political climate hostile to all immigrants, these strengthened powers of detention could very well be used to target the women. The proposed changes also refer explicitly to migrants arriving as part of "criminally organized smuggling operations" as a category for detention. This means that women who are being trafficked, or who have entered the country as a group, with the assistance of smugglers, will be automatically detained. Given that immigration officers already have the power to detain, many refugee-rights groups and refugee lawyers are extremely concerned with the enhancement of this power. They find current provisions quite sufficient. Indeed, as noted in the example of the migrants from China, current powers of detention have resulted in the lengthy 
incarcerations of women, men, and children. Strengthening these powers increases the potential for increased abuse and human rights violations in the treatment of migrants.

\section{Human Smuggling and Trafficking}

The new immigration act proposes to create a new offence of human trafficking. Penalties for this offence would be harsh indeed, with a proposed fine for a first offence of approximately $\$ 500,000$ and/or imprisonment for up to ten years. For a subsequent offence, the proposed fine would be $\$ 1$ million, or imprisonment for up to fourteen years. ${ }^{29}$ For those bringing in ten or more persons, the penalty would be a fine of $\$ 1$ million and/or life imprisonment..$^{30}$ Clearly, the government's repeated statements about getting tough on smugglers and traffickers is reflected in this bill. However, the obsession with stronger sentences and heftier fines for smugglers and traffickers does nothing to address the root causes of trafficking and human smuggling, which are the growing poverty, destitution, and environmental devastation in many countries in the South, as well as the sexualized and gendered exploitation of women.

The myopic focus of the proposed act on harsher penalties can be expected to increase the incentives of smugglers and traffickers to more closely control the women they traffic. Stronger measures against traffickers and smugglers, in the face of failure to address the root causes that support the trafficking of women, will increase the women's vulnerability to the power of the smugglers - a power ultimately dependent upon coercion, threats, and the use of violence.

State targeting of smugglers and traffickers also obscures the reality that as trade liberalization has forced open the economies of previously colonized countries to greater penetration by multinational corporations, the conditions that push women into migration in these countries have been exacerbated. The Canadian state is a leading proponent of free trade and greater trade liberalization, playing a highly visible role in negotiations at the World Trade Organization, and in trade agreements like NAFTA, APEC, and the FTAA. So the state has a direct hand in shaping policies at the global level that are pushing increasing numbers of women into migration and into being trafficked. Considered in this light, the state's construction of smugglers and traffickers as primarily and solely responsible for trafficking allows it to carefully avoid any responsibility for the deteriorating economic conditions within the global economy.

There is ostensibly some room in the proposed legislation for provisions to protect women who are trafficked, on humanitarian and compassionate grounds. For example, such a provision allows that "The Minister may, in the Minister's discretion, examine the circumstances concerning a foreign national who is inadmissible or who otherwise does not meet the requirements of this act, and authorize the foreign national to remain in Canada as a permanent resident if the Minister is of the opinion that it is justified by humanitarian and compassionate considerations relating to the foreign national or by public policy considerations." ${ }^{31}$ Likewise, the minister "must take into account the best interests of a child affected by the decision." ${ }^{2}$ Two points are pertinent here. First, there is absolutely no commitment to the "best interests" of women who are trafficked in this discretionary measure, and second, even if such a commitment could be secured from the minister, this measure would apply only on a discretionary basis, and not become mandatory in every case of trafficking.

The proposed changes also explicitly state, "No person shall knowingly organize the coming into Canada of one or more persons by means of threat, force, abduction, fraud, deception or coercion," and includes the recruitment, transportation, and harbouring of such persons in Canada, ${ }^{33}$ specifying penalties for contravening this as "a maximum fine of $\$ 1,000,000$ or to life imprisonment, or . . both." ${ }^{34}$ Relevant factors to be taken into consideration by the court in such cases include consideration of whether grievous bodily harm or death has occurred, whether the offence was organized by a criminal organization, whether it was undertaken for profit, or whether "a person was subjected to humiliating or degrading treatment, including with respect to work or health conditions or sexual exploitation as a result of the commission of an offence." 35

We know from the experience of front-line workers that sometimes women who have themselves been trafficked, or who work in the sex trade, "help" to recruit other women from their families and communities into the same type of working and living circumstances as themselves. The motives for such help range from financial gain to compassion in aiding other women to find employment and escape poverty. Provisions in the proposed act would make such women subject to tough sentences, and these women, themselves victimized, could be charged with the same crime and with the same penalties to which organized smuggling rings would be subject. The blanket condemnation of "smugglers" and "traffickers" adopted by the proposed legislation suggests that harsh penalties for them will reduce, if not outright end, trafficking. This approach remains wilfully oblivious to the complexities of trafficking, and to myriad ways in which women express their agency, leading many of them to seek out the services of men and 
women who can help them migrate, and to help other women enter into the same forms of migration and work.

As already outlined, the bill stresses stronger sentencing for human smugglers and traffickers, but there is no expressed objective in the proposed act to protect women who have been trafficked and to strengthen their rights. The bill seems based on the misguided assumption that the current practice of deporting women who have been trafficked is the only fair option in dealing with them. As international agencies and local women's organizations who work with trafficked women repeatedly stress, these women often have no family or community support for going back. In fact, quite the opposite is true, as the women can be further stigmatized and ostracized upon return. And often it is family and community pressures that have driven the women into migration and trafficking in the first place. The bill recognizes no such complexities. So, for example, what of family members, who, out of desperation, sell women from their own families? Will they, too, be defined as engaged in "serious criminality" and become inadmissible should they attempt to enter Canada to be reunited with the women who might become landed in Canada? The proposed legislation makes no clear distinction between those who make a clear monetary profit from recruiting, trafficking, and smuggling, and those women, themselves living in vulnerable and desperate circumstances, who decide to "help" other women in their families and communities.

The myopic approach of the proposed changes does, however, enable the Canadian state to deny the reality that the labour of trafficked women serves the interests of certain sectors of the Canadian industry, and benefits individual men and women being served by the women's domestic and sexual labour. The reality is that Canadian interests are served by these women, and recognition of this fact is crucial to accepting that it is the responsibility of the Canadian state to protect the rights of the women, and to offer them this protection, in this country. In treating the women instead as an external problem to be repatriated, the Canadian state helps to preserve the interests of Canadians and their "right" as citizens to benefit from the international trafficking of migrants.

And finally, the proposed changes could have severe consequences for women's groups and other advocates for women who have been trafficked. The proposed legislation states, "Every person who knowingly induces, aids, or abets or attempts to induce, aid or abet any person to contravene section $110,111,112,115,117,122$ or 123 , or who counsels a person to do so, commits an offence and is liable to the same penalty as that person." ${ }^{36}$ This new offence to be created could have extremely serious repercussions for the women's organizations and activists who work with women who have been trafficked, as well as their family members. These organizations, activists, and family members could all become liable to the same sanctions as the women who have been trafficked. Should this provision be implemented, it is quite conceivable that an individual (for example, a family member who has landed immigrant status) or a women's group (such as a rape crisis centre or transition home) that gives sanctuary to a woman who has been trafficked might be charged with aiding and abetting her for this act. Similarly, a person helping a woman who has used forged documents to enter Canada (knowingly or otherwise), or who has managed to escape a violent employer, could be found guilty of aiding and abetting her. With this change, the state is not only targeting women who are trafficked, but also seeks to erode any support they might garner from politically committed and sympathetic sectors within Canada.

In short, then, by focusing on the crime of smuggling and trafficking, the state has made smugglers and traffickers extremely visible, while making the actual women who are smuggled and trafficked invisible. The interests of these women are made as foreign to Canadians as have been the other cultures and countries from which these women come. That the women should be immediately repatriated is the unquestioned and unshaken resolve underpinning the provisions. And although Canada is signatory to the Convention for the Elimination of All Forms of Discrimination against Women (CEDAw), as well as the Beijing Platform for Action and various ILo conventions, nowhere is any specific commitment made in these proposed provisions to protect the rights of women who have been trafficked.

\section{Conclusion}

Trafficking in women is a highly profitable enterprise and serves the Canadian economy and Canadian society. Women who are trafficked, whether entering the country legally or otherwise, are engaged in entertainment and sex industries, as well as in domestic work. These women serve the interests of the employers who hire them, as well as the interests of individual Canadian men and women, by their sexual and domestic labour. Yet, the sanctions and punishments imposed by the state ultimately penalize the women, through deportation, and not the Canadian men, women, and employers who profit and benefit from the women's exploitation.

The current restructuring of the immigration program, which includes the introduction of the new act, will make immigration for permanent settlement (with landed im- 
migrant status) from the countries of the South-and in particular, of poor and working women from the Southextremely restrictive. These restrictive measures can be expected to push many would-be immigrant women, who might otherwise have entered the country with landed status, into becoming migrants, whether legal or otherwise. As immigration for legal, permanent settlement into Canada is made more difficult for people from the South, we can expect an increase in extra-legal forms of migration. Likewise, the significant growth of unemployment globally and the expansion of the informal sectors, both of which have become key features of the restructuring of the global economy, will further escalate migrations from the South into the North. Therefore, the current direction of Canadian immigration policy needs to change on the principles of social justice and gender equity if the interests of women who are trafficked are to be served. While such a transformation requires fundamental and far-reaching changes to the workings of the global economy, one immediate step would be to make landed immigrant status mandatory for women who have been trafficked. For ultimately it is women from the South who, as a result of the international division of labour-based on race, gender, and class - pay the heaviest costs of the restrictive immigration policies of the countries of the North, including Canada.

\section{Notes}

1. The proposed new act, Bill C-31, was tabled in June 2000. However, a federal election was called before it could be passed. The bill nevertheless outlines the Liberal government's approach to immigration, and for dealing with trafficking. With the Liberal Party having won the federal election of November 2000, we can anticipate a resurrection of the bill during the current mandate of the government.

2. This paper is based, in part, on research I undertook as a research partner in a project for the Global Alliance against Trafficking in Women (GAATW), during the summer of 2000.

3. Francisco Rico-Martinez, "Bolting Back Door Raises Issues," Windsor Star, May 23, 2000.

4. Marjan Wijers defines trafficking as follows:

"Traffic in women" is a broad category covering various forms of exploitation and violence within a range of (informal) labor sectors that migrant women work in, including prostitution, entertainment industries and domestic work. Trafficking is not limited to prostitution, although this is the popular belief, and not all prostitution involves trafficking. We can define trafficking in the narrow sense as the process in which migrant women are brought into prostitution through the use of coercion, deceit, abuse or violence and in which they are denied fundamental human rights and freedoms such as the right to decide to work as a prostitute or not, the right to decide on the conditions of work, the right to enter and leave the sex industry, the right to refuse certain customers, the right to freedom of move- ment, the right not to be exploited, and so forth. If trafficking is defined in a broader sense it can apply not only to prostitution, but also to other forms of labor such as those mentioned above (M. Wijers, "Women, Labor, and Migration: The Position of Trafficked Women and Strategies for Support," in Global Sex Workers: Rights, Resistance, and Redefinition, eds. K. Kempadoo and J. Doezema (New York: Routledge, 1998), 69-78.

5. For a fuller discussion, see Sietske Altink, Stolen Lives: Trading Women into Sex and Slavery (London: Scarlet Press, 1995).

6. See the case studies by Jo Bindman, Amalia Lucia Cabezas, John K. Anarfi, and Coco Fusco, among others, in Global Sex Workers: Rights, Resistance and Redefinition, eds. K. Kempadoo and J. Doezema (New York: Routledge, 1998). Also see Yasmin Jiwani, Trafficking and Sexual Exploitation of Girls and Young Women: A Review of Select Literature and Current Initiatives (Vancouver: FREDA, June 1999).

7. Altink Sietske has pointed to the "tension between the desire of the Third and Second World peoples to migrate to the First World and the restrictions western countries place on immigration" (Sietske, Stolen Lives, 4). It is in this "tension" that traffickers organize their activities, she has argued. In a similar vein, Audrey Macklin states, "Women migrants often embody-literally-the absence, breakdown, or the inequities of the international law regime." See A. Macklin, "Women as Migrants in National and Global Communities," Canadian Woman Studies 19, no. 3 (1999), 24.

8. GaATw Project Proposal, Trafficking in Women: The Canadian Dimension (Victoria: GAATW, 1999), 1.

9. The PWC and GAATW use the term immigrant brides, as the term mail-order bride does not adequately capture the circumstances of some of the Filipina women they interviewed. Whereas a mail-order bride is bought for a fee, these Filipina women had often met and married men travelling to Asia looking for wives, or had been introduced by a friend. See appendix 1, in The Philippine Women's Centre and GAATw, Echoes: Cries for Freedom, Justice and Equality (Vancouver: GAATW \& PWC, 1999).

10. Jyoti Sanghera, "Report from the North American Region," in Whores, Maids \& Wives (Victoria: GaATW, 1998), 24-8.

11. GAATW Project proposal submitted to Status of Women Canada, Trafficking in Women: The Canadian Dimension (Victoria: GAATW, 1999).

12. See Sanghera, "Report," 26.

13. The Philippine Women's Centre (PWC) and GaATw. Echoes: Cries for Freedom, Justice and Equality (Vancouver: GAATW \& PWC, 1999).

14. The term illegal migrants is used most frequently in the public discourse about this particular group of migrants. The distinction between legal and illegal migrants speaks more to the state's strategy of seeking to gain, and maintain, control over immigrants and migrants than it does to the root causes of migration or to the lived experiences of the migrants themselves. I therefore use the term extra-legal in order to draw attention to the social construction of legality and illegality through which the state seeks to exercise its control over international migrations.

15. In Canada, the high-profile arrival of several groups of Chinese migrants into British Columbia by boat in the summer of 1999 drew a great deal of public attention to this group. The 
arrival of these migrants was thoroughly exploited by the Canadian government to build political support for introducing increasingly restrictive measures for future immigration, as I have discussed elsewhere. See "Forum on Migrants," Kinesis, April 2000.

16. Citizenship and Immigration Canada, Fact Sheet \# 7: Sponsorship, online: $<$ http://canadavisa.com $>$.

17. Sanghera, "Report," 24-8.

18. Section 11 (2) states specifically, "The designated officer may not issue a visa or document to a foreign national whose sponsor does not meet the sponsorship requirements of this Act." Further, 13 (3) states, "An undertaking relating to sponsorship is binding on the person who gives it."

19. Section 35 states, "A foreign national, other than a permanent resident, is inadmissible for financial reasons if the foreign national is or will be unable or unwilling to support himself or herself or any other person who is dependent on them, and has not satisfied a designated officer that adequate arrangements for care and support, other than those that involve social assistance have been made."

20. Section 34 (c), Bill c-31.

21. For a fuller discussion of this point, see Sunera Thobani, "Sponsoring Immigrant Women's Inequalities," Canadian Woman Studies 19, no. 3 (fall 1999): 11-16.

22. PWC and GAATW, Echoes, 8.

23. GAATW, Trafficking in Women.

24. See PWC and GAATw, Echoes, as well as Daiva Stasiulis, "Keynote Address," Whores, Maids and Wives: Making Links (Victoria: GAATW, 1998), 29-37.

25. Legal worker, Metro Toronto Chinese and South East Asian Legal Clinic, telephone interview, June 2000.

26. GAATW, Trafficking in Women.

27. By January 2000, only 4 per cent of the completed claims for asylum made by the 493 Chinese migrants were actually granted refugee status. The overall acceptance rates for refugee claimants are about 55 per cent overall, and the acceptance rate for claimants from China in 1998-9 was 44 per cent. See Chad Skelton, "Refugee Claim Accepted for Fourth Chinese Migrant," Vancouver Sun, January 17, 2000.

28. See Sections 50 (b) and 51 (2) (a) (i) of Bill C-31.

29. See Section 110 (2) (a) and (b) of Bill c-31.

30. See Section 110 (3)

31. Section 22 (1), Bill C-31.

32. Section 22 (2), Bill C-31.

33. Section 111 (1) and (2), Bill C-31.

34. Section 113 and 114, Bill C-31.

35. See Section 114 (1) (d), Bill c-31.

36. Section 124, Bill c-31

Sunera Thobani teaches women's studies at the University of British Columbia. She has worked in feminist and antiracist organizations, and is a past-president of the National Action Committee on the Status of Women, Canada's largest feminist organization.

(C) Sunera Thobani, 2001. This open-access work is licensed under a Creative Commons Attribution-NonCommercial 4.0 International License, which permits use, reproduction and distribution in any medium for non-commercial purposes, provided the original author(s) are credited and the original publication in Refuge: Canada's Journal on Refugees is cited. 